\section{Commentary: The rising storm of atrioesophageal fistulae after catheter ablation for atrial fibrillation}

\author{
K. Robert Shen, MD
}

In this case report, Gibney and colleagues ${ }^{1}$ describe the successful management of an atrioesophageal fistula (AEF) that developed as a complication of previous percutaneous ablation for atrial fibrillation. This timely report addresses a rare but highly lethal clinical scenario that all thoracic surgeons will increasingly face in the future.

Catheter ablation has recently become a cornerstone of therapy for patients with paroxysmal and chronic atrial fibrillation. Recent large randomized trials, such as the CASTLE-AF and CABANA trials, ${ }^{2,3}$ demonstrating the benefits of catheter ablation for atrial fibrillation are expected to lead to an increased number of atrial fibrillation ablations performed worldwide.

As the authors have noted, because the development of AEF is a rare but highly lethal complication of catheter ablation for atrial fibrillation, early recognition of the complication and prompt surgical intervention is imperative. In literature reviews of all reported patients with AEF after catheter ablation for atrial fibrillation, fever and neurologic deficits were the most common presenting symptoms, and the 2012 Heart Rhythm Society consensus statement on catheter and surgical ablation of atrial fibrillation has highlighted these 2 symptoms. ${ }^{4}$

\footnotetext{
From the Division of General Thoracic Surgery, Department of Surgery, Mayo Clinic, Rochester, Minn.

Disclosures: The author reported no conflicts of interest.

The Journal policy requires editors and reviewers to disclose conflicts of interest and to decline handling or reviewing manuscripts for which they may have a conflict of interest. The editors and reviewers of this article have no conflicts of interest.

Received for publication Dec 13, 2020; revisions received Dec 13, 2020; accepted for publication Dec 21, 2020; available ahead of print Dec 25, 2020.

Address for reprints: K. Robert Shen, MD, Division of General Thoracic Surgery, Department of Surgery, Mayo Clinic, 200 First St SW, Rochester, MN 55905 (E-mail: Shen.KRobert@mayo.edu).

JTCVS Techniques 2021;6:169

2666-2507

Copyright (C) 2021 The Authors. Published by Elsevier Inc. on behalf of The American Association for Thoracic Surgery. This is an open access article under the CC BY-NCND license (http://creativecommons.org/licenses/by-nc-nd/4.0/).

https://doi.org/10.1016/j.xjtc.2020.12.013
}

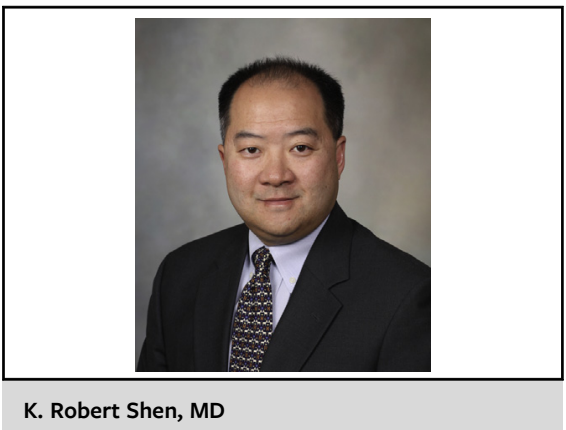

\section{CENTRAL MESSAGE \\ Atrioesophageal fistula is a rare but highly lethal complication after catheter ablation for atrial fibrillation that thoracic surgeons will increasingly be asked to manage.}

Other take-home messages:

1. Chest and head CT scans seem to be the most useful and accurate diagnostic modality for identifying AEF.

2. According to the Heart Rhythm Society, endoscopy should be avoided, because it could lead to massive air embolism with resulting stroke and possible death. ${ }^{4}$

3. Interposition of healthy vascularized tissue between the repaired esophagus and atria is worthwhile to lower the risk of recurrent fistula.

4. Preparations should be made to use cardiopulmonary bypass if necessary during the surgical repair of the AEF because, depending on the location of the fistula, the left atrium may need to be explored.

\section{References}

1. Felmly LM, Gibney BC. Atrioesophageal fistula from percutaneous ablation for atrial fibrillation. J Thorac Cardiovasc Surg Tech. 2021;6:167-8.

2. Marrouche NF, Brachmann J, Andresen D, Siebels J, Boersma L, Jordaens L, et al CASTLE-AF Investigators. Catheter ablation for atrial fibrillation with heart failure. N Engl J Med. 2018;378:417-27.

3. Packer DL, Mark DB, Robb RA, Monahan KH, Bahnson TD, Moretz K, et al CABANA Investigators. Catheter ablation versus antiarrhythmic drug therapy for atrial fibrillation (CABANA) trial: study rationale and design. Am Heart J. 2018;199:192-9.

4. Calkins H, Kuck KH, Cappato R. 2012 HRS/EHRA/ECAS expert consensus statement on catheter and surgical ablation of atrial fibrillation: recommendations for patient selection, procedural techniques, patient management and follow-up, definitions, endpoints, and research trial design. Europace. 2012;14:528-606. 